\title{
Effect of Dietary Protein against Excess Vitamin A Induced Hepatotoxicity in Rats
}

\section{PK Karar*, Gaurav Agarwal, Shilpi Agarwal and Manish Devgan}

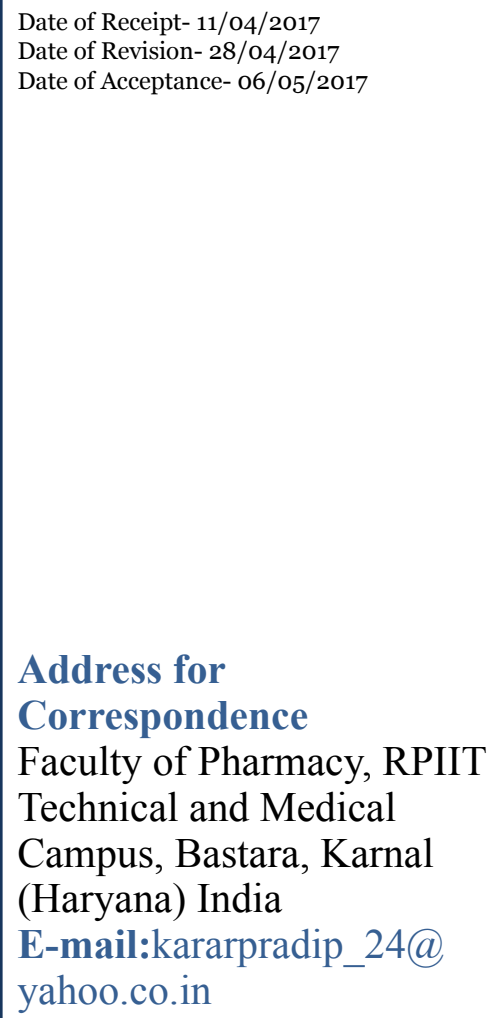

\section{Address for}

Correspondence

Faculty of Pharmacy, RPIIT

Technical and Medical

Campus, Bastara, Karnal

(Haryana) India

E-mail:kararpradip_24@

yahoo.co.in

\begin{abstract}
Vitamin A deficiency is a serious nutritional deficiency disease. In most cases vitamin A deficiency is associated with protein malnutrition. Excess vitamin A cannot be transported for want of transport protein. We aimed to investigate the quantity of protein required in diet to protect excess vitamin A fed hepatotoxicity in rats. Normal and excess amount of vitamin A (4000 IU/kg and $40000 \mathrm{IU} / \mathrm{kg})$ ) with three different levels of dietary protein $(6 \%, 18 \%$ and $30 \%)$ were administered orally for 30 consecutive days in rats. In low protein diet vitamin A level significantly increased in liver and decreased in plasma and, lipids level were found to be high in liver. Administration of excessive doses of vitamin A resulted in significant decrease in the levels of serum and liver RBP. Excess vitamin A in low protein state significantly induced oxidative stress in the liver, leading to increased serum levels of liver enzyme markers aminotransferases, total and direct bilirubin. Lipid remains in liver for want of transport protein and aggravates the formation of fatty liver. Both lipids and lipoprotein levels are also measured to assess the liver function in hypervitaminosis; a state where abnormally high storage levels of vitamins can lead to toxic symptoms.
\end{abstract}

Keywords: Hepatotoxicity, Vitamin A, Protein, Marker enzymes, Lipoprotein.

\section{INTRODUCTION}

Vitamin A deficiency (VAD) has been recognized as a public-health issue in developing countries like India which has the highest clinical and sub clinical VAD among south Asian countries ${ }^{1,2}$. The regulatory authorities of some of these countries advice to supplement mega doses of vitamin A through diet or other ways as a prophylactic vitamin A therapy in vitamin A deficient condition ${ }^{3}$. But studies indicated that persons suffering from protein malnutrition had decreased plasma level of vitamin A which was due to functional impairment in the hepatic release of vitamin A rather than body Vitamin A deficiency, reduced synthesis of Retinol Binding Protein (RBP), a transport protein for vitamin A, may be responsible for impairment in the hepatic release of vitamin $\mathrm{A}^{4}$. Retinol bound to RBP does not appear to manifest its surface active effects on biological membranes; rather the mode of transport of vitamin A may be an important determinant of the development of the manifestations of hypervitaminosis A5. In fact plasma lipoproteins may nonspecifically deliver vitamin A to biological membranes and leads to vitamin A toxicity ${ }^{5}$.

Amount of protein intake influences the normal transport of vitamin A and its metabolism, protein deficiency also affects the formation of lipoprotein which transports lipid, transport of lipid is affected and lipid remains in liver and helps to form fatty liver ${ }^{6}$. Lipoprotein in serum and liver were determined to verify this fact. Excess level of vitamin A is known to be hepatotoxic ${ }^{7}$. Marker enzymes AST, ALT and bilirubin were, therefore, measured to assess the hepatotoxicity.

Therefore, the aim of this study was to determine the quantity of protein required for the normal transport of vitamin $\mathrm{A}$ in presence of different vitamin A conditions. Information about the transport of vitamin 
A in hypervitaminotic A rats is also presented.

\section{MATERIALS AND METHODS}

\section{Chemicals}

Analytical grade all trans retinol was obtained from as gift. All other chemicals and reagents used in this study were of high analytical grade and were used without further modifications.

\section{Experimental Animals}

Healthy four months old male albino rats of Wister strain weighing 140-160 g were used in this investigation. Animals were individually housed in poly propylene cages in air-conditioned room maintained at $25 \pm 2^{\circ}$ with regular $12 \mathrm{~h}$ light $/ 12 \mathrm{~h}$ dark cycle. They all were provided with modified diet. Free access to food and water ad libitum was provided. All the procedures involving the animals were in accordance with the Animal Ethical Committee.

\section{Modified Diet Composition And Their Preparation}

The compositions of $1 \mathrm{~kg}$ standard diet and other experimental diets are as follows:

Group I (control) diet and group IV diet contains $180 \mathrm{~g}$ casein, $670 \mathrm{~g}$ rice starch, $40 \mathrm{~g}$ salt mixture $100 \mathrm{~g}$ ground nut oil and $10 \mathrm{~g}$ vitamin mixture.

Group II diet and group V diet contains $60 \mathrm{~g}$ casein, $790 \mathrm{~g}$ rice starch and other constituents were same as control diet.

Group III diet and group VI diet contains $300 \mathrm{~g}$ casein, $550 \mathrm{~g}$ rice starch and other constituents were same as control diet.

Powdered retinyl palmitate tablet $(50,000 \mathrm{IU})$ was mixed with the diet at $4000 \mathrm{IU} / \mathrm{kg}$ and $40,000 \mathrm{IU} / \mathrm{kg}$ as per protocol.

\section{Experimental Design}

Animal groups: 36 rats were divided into 6 equal groups (Group I-VI). Rats were individually housed in poly propylene cages in a room at $25^{\circ} \pm 2^{\circ} \mathrm{C}$. Each rat was given $20 \mathrm{~g}$ diets per day for 30 days. Groups I, II and III were fed normal level of vitamin A $(4,000 \mathrm{IU} / \mathrm{kg}$ diet $)$ containing diets whereas groups IV, $\mathrm{V}$ and VI were fed excess level of vitamin A (40,000 IU/ $\mathrm{kg}$ diet) containing diets. Groups I and IV diets were treated with normal level of casein $(18 \%)$, groups II and V diets were treated with low level of casein $(6 \%)$ and groups III and VI diets were treated with excess level of casein (30\%). All the administered diets (Groups I-VI) were made isocaloric by keeping the total weights of protein (casein) and carbohydrate (rice starch) same and by adding same amount of lipid (ground nut oil) per $\mathrm{kg}$ of diet.

Rats were kept overnight fasting at the end of 30 days experimental period; blood was collected by cardiac puncture under light ether anesthesia and then sacrificed. The liver was excised promptly, washed in cold normal saline, blotted dry and immediately transferred to ice chamber. Part of liver tissue was preserved in 10\% formalin for histopathological studies.

Measurement of experimental parameters in serum and liver: The protein content in plasma/ liver homogenate was estimated using the method of Lowry ${ }^{8}$. Vitamin A from liver was extracted by the method of Ames ${ }^{9}$ and subsequently estimated from the cholesterol phase by Carr Price method $^{10}$. Vitamin A in plasma was determined by Jalal HPLC method ${ }^{11}$. Plasma and liver lipids were extracted by the method of Folch ${ }^{12}$. Plasma and tissue cholesterol, triacylglycerols and phospholipids were estimated by Zlatkis ${ }^{13}$, Nagele $^{14}$ and Zilversmith ${ }^{15}$ methods respectively. ALT and $\mathrm{AST}^{16}$, bilirubin direct and tota ${ }^{17}$ were determined using modified microassay method. The RBP levels in serum and liver samples were determined by radioimmunoassay method ${ }^{18}$.

\section{Statistical Analysis}

Results expressed are the mean \pm SE of 6 rats in each group. Data were subjected to statistical analysis through one-way analysis of variance (ANOVA). Student's t test was used to determine the statistical significance between control and test groups. Significance level was fixed at 0.05 .

\section{RESULTS}

Rats received low level of dietary protein showed significant increase level of vitamin A in liver accompanied by a corresponding decrease level in plasma (Group II, Table 1). Rats received high level of dietary protein showed exactly opposite levels in both liver and plasma (Group III, Table 1). All the excess vitamin A treated rats showed higher vitamin A values in both liver and plasma compared to their respective control rats (Groups IV to VI, Table 1). Low amount of dietary protein fed rats showed increase values of lipid profiles in liver but decrease values in plasma, reversed 
values were obtained in high amount of dietary protein fed rats (Groups II and III, Table 2). Effects of dietary protein on lipid profile were more pronounced in excess vitamin A treated rats (Groups III, IV and V, Table 2).

A significant increase of serum ALT and AST levels and slight decrease of liver AST and ALT levels were seen in low dietary protein fed condition, a slight decrease of serum AST and ALT levels and moderate increase of liver ALT and AST levels were seen in high dietary protein fed condition compared to their normal groups (Groups II and III, Table 1). Excess vitamin A treated rats (Groups IV, V and VI) showed similar trend of results of ALT and AST with more expressive effects. In low protein fed condition both direct and total bilirubin values were increased and in high protein fed condition these values were decreased (Groups II and III, Table 1). Similar trends of values too were seen in excess vitamin A fed condition but all values were found to be more expressive compared to normal vitamin A fed diets. Retinol binding protein level (RBP) in liver showed slight reduced value in low protein fed condition and higher value in high protein fed condition, excess vitamin A fed rats showed higher values compared to normal vitamin A fed rats. Same trend of results of RBP was seen in plasma in normal vitamin A treated rats but excess vitamin A treated rats showed reduced values compared to normal vitamin A treated rats.

\section{DISCUSSION}

Increased level of vitamin A in liver and decreased level in plasma in low protein fed rats was due to decrease synthesis of vitamin A transport protein, retinol binding protein (RBP). $\mathrm{RBP}$ is responsible for the transport of vitamin A from liver to plasma ${ }^{19}$. The situation was reversed in liver when protein intake was more due to excess transport of vitamin A from liver to plasma. The condition became worse when excess vitamin A was supplemented in diet, due to excess storage of vitamin A in liver. It was alarming in low dietary protein condition since very high accumulated vitamin A may manifest its toxic effects.

Insufficient protein in diet decreases the synthesis of Apo protein which in turn affects the synthesis of lipoprotein ${ }^{20}$. Transport of cholesterol, triacylglycerol and phospholipids are affected for want of lipoprotein, they remain in liver and may help to form fatty liver ${ }^{21}$. This was consistent with the increase levels of the lipids in liver in low protein fed rats. Excess intake of vitamin A requires additional amount of RBP. It appears that there was a diversion of amino acids in liver for the synthesis of additional RBP as a result less amount of lipoproteins was available for lipid transport. This may lead to deposit of more lipids in liver and help the formation of fatty liver. An increased level of ALT and AST in serum in low dietary protein fed rats was due to enhance transamination to metabolize the excess amino acids release from tissue breakdown to compensate low dietary protein ${ }^{22}$. Significantly increased levels of serum ALT and AST in all the excess vitamin A supplemented rats is due to toxic effects of vitamin A on liver ${ }^{23}$. High serum levels of ALT and AST were due to leakage of the enzymes from liver as a result of tissue damage. Levels of these enzymes are particularly high in group $\mathrm{V}$ when very high amount of vitamin A are accumulated due to low dietary protein. Both total and direct bilirubin levels were also found to be high in plasma in this group. All these factors are the sign of liver damage.

Administration of high doses of vitamin A resulted in substantial decrease in the level of RBP in plasma (Groups IV, V and VI). It is possible that excess vitamin A leads to decreased rates of RBP synthesis in liver and decreased RBP secretion from liver, resulted increased values of RBP in liver in excess vitamin A fed rats $^{24}$.

\section{CONCLUSION}

It can be concluded that RBP is responsible for the transport of vitamin A from liver to plasma. The Increased level of vitamin A in liver and decreased level in plasma in low protein fed rats is due to decrease synthesis of vitamin $A$ transport protein, retinol binding protein (RBP). It was alarming in low dietary protein condition since very high accumulated vitamin A may manifest its toxic effects.

Insufficient protein in diet decreases the synthesis of Apo protein which in turn affects the synthesis of lipoprotein. Excess intake of vitamin A requires additional amount of $\mathrm{RBP}$. This may lead to deposit of more lipids in liver and help the formation of fatty liver. Administration of high doses of vitamin A resulted in substantial decrease in the level of RBP in plasma (Groups $\mathrm{IV}, \mathrm{V} \& \mathrm{VI})$. Hence not only an increase in 
Vitamin A intake will help but it should be supplemented with an intake of normal protein diet which will help in fighting against the condition of hypovitaminosis otherwise it will lead to reverse the condition i.e. It will result in hypervitaminosis.

\section{REFERENCES}

1. Saeed A. Vitamin A deficiency (VAD) has been recognized as a public health issue in developing countries- Prevalence of vitamin A deficiency in South Asia: Causes, outcome and possible remedies. J Health Popul Nitr. 2013;31:413-23.

2. Arlappa N. Vitamin A deficiency is still a public health problem in India. Indian Pediatr. 2011;48:853-54.

3. Lathan M. The great vitamin A fiasco. World Nutrition. 2010;11:12-45.

4. Semba RD. Assessment of vitamin A status of preschool children in Indonesia using plasma retinol- binding protein. J Trop Pediatr. 2002;48:84-7.

5. Baert E. The retinoids in plasma retinol binding protein. Academic Press, London. 2014;2:79.

6. Karar PK. Effect of dietary protein on vitamin A levels in plasma and liver in hypervitaminotic A rats. Indian J Exp Biol. 2002;40:355-58.

7. Leo MA. Hypervitaminosis A: Liver lover's lament. Hepatology. 1988;8:41216.

8. Lowry OH. Protein measurement with folin reagent. J Biol Chem. 1951;193:265-75.

9. Ames SR. Simplified procedure for extraction and determination of vitamin A in liver. Anal Chem. 1954;378-81.

10. Carr TH. Color reaction attributed to vitamin A. Biochem J. 1926;497-501.

11. Jalal F. Serum retinol concentrations in children are affected by food sources of $\beta$ carotene, fat intake and anthelmintic drug treatment. Am J Clin Ntur. 1998;68:62329.

12. Folch J. A simple method for the isolation and purification of total lipids from animal tissues. J Biol Chem. 1957;226:497-99.

13. Zlatkis A. A new method for the direct determination of serum cholesterol. Lab Clin Med. 1953;41:486-92.

14. Nagele A. Reagent for the enzymatic determination on serum total triglycerides with improved lipolytic efficiency. J Clin Chem Clin Biochem. 1884;22:165-64.

15. Zilversmith DB. Micro determination of plasma phospholipids by trichloro acetic acid precipitation. J Lab Clin Med. 1950;35:155-60.

16. Bergmeyer HU. Glutamate oxaloacetate transaminase; glutamate pyruvate transaminase in methods of enzymatic analysis. Academic Press, New York. 1963;837-53.

17. Aman A. Estimation of total and direct bilirubin using modified micro assay method. Ital J Biochem. 2007;2:171-75.

18. Noriaki A. Radio immune assay studies of the tissue distribution and subcellular retinol binding protein in rats. Journal of Biological Chemistry. 1981;256:9471-6.

19. Mahmood K. Serum retinol binding protein as an indicator of vitamin A status in cirrhotic patients with night blindness. Saudi J Gastroenterol. 2008;14:7-11.

20. Madani S. Dietary protein level and origin (casein and highly purified soybean protein) affect hepatic storage, plasma lipid transport and antioxidative defense status in the rat. Nutrition. 2000;16:368-75.

21. Klementina FT. Nonalcoholic fatty liver disease: Focus on lipoprotein and lipid deregulation. J Lipids. 2011.

22. Chowdhury MSI. Serum aspartate aminotransferase (AST) and alanine aminotransferase (ALT) levels in different grades of protein energy malnutrition. J Bangladesh Soc Physiol. 2007;2:17-9.

23. Choudhary PR. Hypervitaminosis is associated with increased risk of hepatotoxicity in swiss albino mice. Int $\mathbf{J}$ Biol Med Res. 2012;3:1311-4.

24. Mallia AK. Metabolism of Retinol Binding Protein and vitamin A during hytervitaminosis $\mathrm{A}$ in rat. J Lipid Res. 1975;16(3):180-8. 
Table 1. Effect of dietary protein on vitamin A, RBP, ALT, AST and bilirubin levels in Hypervitaminotic A rats

\begin{tabular}{|c|c|c|c|c|c|c|}
\hline Parameters & Group I & Group II & Group III & Group IV & Group V & Group VI \\
\hline $\begin{array}{l}\text { Vitamin A in } \\
\text { liver }(\mu \mathrm{g} / \mathrm{g})\end{array}$ & $180.86 \pm 16.12$ & $358.64 \pm 17.93$ & $44.28 \pm 6.02$ & $234.66 \pm 7.12$ & $575.32 \pm 3.29$ & $116.54 \pm 6.78$ \\
\hline $\begin{array}{l}\text { Vitamin A in } \\
\text { plasma }(\mu \mathrm{g} / \\
\mathrm{dl})\end{array}$ & $25.44 \pm 7.85$ & $17.88 \pm 4.44$ & $39.11 \pm 5.49$ & $32.20 \pm 3.36$ & $19.56 \pm 3.11$ & $45.19 \pm 5.31$ \\
\hline $\begin{array}{c}\text { RBP in liver } \\
(\mathrm{ng} / \mathrm{mg})\end{array}$ & $201.83 \pm 11.29$ & $175.29 \pm 3.45$ & $206.42 \pm 6.39$ & $216.22 \pm 6.69$ & $184.76 \pm 9.42$ & $238.39 \pm 6.08$ \\
\hline $\begin{array}{c}\text { RBP in } \\
\text { plasma }(\mu \mathrm{g} / \\
\mathrm{ml})\end{array}$ & $52.51 \pm 2.11$ & $46.37 \pm 3.34$ & $58.82 \pm 0.85$ & $44.11 \pm 4.12$ & $40.82 \pm 1.74$ & $51.97 \pm 4.06$ \\
\hline $\begin{array}{l}\text { ALT in liver } \\
(\mathrm{U} / \mathrm{L})\end{array}$ & $35.30 \pm 5.79$ & $32.88 \pm 6.29$ & $46.44 \pm 3.69$ & $30.32 \pm 1.87$ & $27.85 \pm 4.37$ & $36.28 \pm 0.46$ \\
\hline $\begin{array}{c}\text { ALT in } \\
\text { Plasma } \\
(\mathrm{U} / \mathrm{L})\end{array}$ & $20.58 \pm 1.21$ & $41.62 \pm 5.56$ & $17.75 \pm 4.76$ & $39.32 \pm 7.54$ & $124.90 \pm 1.66$ & $36.77 \pm 5.07$ \\
\hline $\begin{array}{l}\text { AST in liver } \\
(\mathrm{U} / \mathrm{L})\end{array}$ & $25.33 \pm 5.47$ & $22.43 \pm 0.59$ & $39.06 \pm 2.95$ & $32.98 \pm 1.74$ & $29.29 \pm 8.32$ & $42.72 \pm 3.56$ \\
\hline $\begin{array}{l}\text { AST in } \\
\text { plasma } \\
(\mathrm{U} / \mathrm{L})\end{array}$ & $14.54 \pm 6.55$ & $34.86 \pm 2.05$ & $12.95 \pm 3.77$ & $31.05 \pm 4.50$ & $98.05 \pm 4.45$ & $29.39 \pm 4.68$ \\
\hline $\begin{array}{c}\text { Direct } \\
\text { bilirubin } \\
\text { in plasma } \\
(\mathrm{mg} / \mathrm{g})\end{array}$ & $0.19 \pm 0.36$ & $0.32 \pm 0.06$ & $0.12 \pm 3.71$ & $0.42 \pm 6.12$ & $1.26 \pm 4.29$ & $0.38 \pm 2.87$ \\
\hline $\begin{array}{c}\text { Total } \\
\text { bilirubin in } \\
\text { plasma (mg/ } \\
\text { dl) }\end{array}$ & $0.42 \pm 2.36$ & $0.71 \pm 0.11$ & $0.34 \pm 2.33$ & $0.61 \pm 3.45$ & $1.79 \pm 1.56$ & $0.42 \pm 1.98$ \\
\hline
\end{tabular}

Table 2. Effect of dietary protein on lipid profile in hypervitaminotic A rats

\begin{tabular}{|c|c|c|c|c|c|c|}
\hline Parameters & Group I & Group II & Group III & Group IV & Group V & Group VI \\
\hline $\begin{array}{c}\text { Total } \\
\text { cholesterol in } \\
\text { liver (mg/g) }\end{array}$ & $2.75 \pm 0.19$ & $3.12 \pm 0.12$ & $2.42 \pm 0.12$ & $2.86 \pm 0.17$ & $3.38 \pm 0.08$ & $2.54 \pm 0.11$ \\
$\begin{array}{c}\text { Total } \\
\text { cholesterol in } \\
\text { plasma (mg/dl) }\end{array}$ & $61.96 \pm 2.24$ & $45.46 \pm 3.31$ & $87.29 \pm 2.81$ & $68.06 \pm 2.37$ & $55.84 \pm 0.47$ & $99.32 \pm 3.81$ \\
$\begin{array}{c}\text { Triacylglycerol } \\
\text { in liver (mg/g) }\end{array}$ & $2.48 \pm 0.05$ & $2.92 \pm 0.06$ & $2.06 \pm 0.08$ & $2.61 \pm 0.05$ & $3.37 \pm 0.18$ & $2.25 \pm 1.12$ \\
\hline $\begin{array}{c}\text { Triacylglycerol } \\
\text { in plasma (mg/ } \\
\text { dl) }\end{array}$ & $84.78 \pm 2.71$ & $70.90 \pm 3.23$ & $106.81 \pm 6.21$ & $91.31 \pm 3.15$ & $82.42 \pm 3.94$ & $117.88 \pm 9.29$ \\
\hline $\begin{array}{c}\text { Phospholipids } \\
\text { in liver (mg/g) }\end{array}$ & $6.04 \pm 0.62$ & $7.87 \pm 0.70$ & $4.82 \pm 0.61$ & $7.24 \pm 0.38$ & $9.21 \pm 0.64$ & $5.51 \pm 0.18$ \\
\hline $\begin{array}{c}\text { Phospholipids } \\
\text { in plasma } \\
\text { (mg/g) }\end{array}$ & $101.74 \pm 4.93$ & $86.17 \pm 4.63$ & $123.36 \pm 5.81$ & $112.22 \pm 5.35$ & $96.53 \pm 4.80$ & $132.29 \pm 5.08$ \\
\hline
\end{tabular}

